\title{
Bulgarian Film Industry: Assessment through Market Mapping
}

\author{
Bilyana Tomova
}

Department of Media and Public communications, University of National and World Economy, 8th December str., Sofia 1700, Bulgaria

\begin{tabular}{|c|c|}
\hline & Abstract \\
\hline $\begin{array}{l}\text { Keywords: } \\
\text { Film Industry, } \\
\text { Economic Contribution, } \\
\text { Mapping, Sustainable } \\
\text { Development }\end{array}$ & $\begin{array}{l}\text { This article is based on the annual empirical survey on the mapping of cultural and } \\
\text { creative industries conducted by the Observatory of Cultural Economics - Sofia. The } \\
\text { survey covers the period } 2008-2015 \text {, which allows the emergence of major trends in } \\
\text { the development of the film industry in Bulgaria. The aim is not only to assess the } \\
\text { economic contribution of the film industry, but also the characteristics of cinema in }\end{array}$ \\
\hline $\begin{array}{l}\text { Received } \\
13 \text { October } 2017\end{array}$ & $\begin{array}{l}\text { Bulgaria as a market sector by analyzing economic growth, employment, and } \\
\text { investment. In this aspect, problems are also addressed in the different stages of }\end{array}$ \\
\hline $\begin{array}{l}\text { Received in revised form } \\
16 \text { May } 2018\end{array}$ & $\begin{array}{l}\text { creating the value of the product from idea to screen, the analysis reflecting the } \\
\text { management of the process, and the role of the state. Beyond the mapping method, }\end{array}$ \\
\hline $\begin{array}{l}\text { Accepted } \\
20 \text { May } 2018 \\
\end{array}$ & $\begin{array}{l}\text { through assessment and analysis of the product and environment, factors (legislative, } \\
\text { management) and recommendations for sustainable sector development are identified. }\end{array}$ \\
\hline
\end{tabular}

(C)AIMI Journals

\section{Introduction}

In past years, a tendency and a public debate with pride and hope for the so-called new wave of Bulgarian cinema appeared. It is connected with the re-establishment of the national film industry.

The film industry not only creates employment and entertainment, but it is also a cultural product. For Europe, Bulgaria, and for most of the countries subsidizing this industry, cinema has never been just an economy, but also a form of politics, a propaganda of a way of life, and of course a cultural phenomenon.

After 1989, Bulgaria started economic and political transition from a state-planned economy to a market economy. The Bulgarian film industry was among the first reformed 
spheres, but the state is stepping down consistently and without a vision of the future and without specialized regulatory tools.

The consequences for the Bulgarian cinema were severe. In the $90 \mathrm{~s}$, film production collapse set in and from 25 to 30 feature films per year, only 2 to 3 films were made. During the same period more than $80 \%$ of employees in the sector were made redundant. Against a unified, huge government structure, the first independent micro-production companies began to emerge, but these were not sustainable without state support. This instability does not reflect the lack of talent, but is purely the outcome of economic factors. Bulgaria is a relatively small European country and a closed linguistic community. This fact predetermines a difficult economy from the scale of production to the distribution of the product.

The film industry has began to awaken from this collapse just after 2004. The special sector rules for financial support were created through the "Bulgarian Film Industry Act". On this basis, the state is systematically subsidizing the sector. The subsidy is on a project by project basis and by means of a bidding procedure. Public funding covers $50 \%$ to $80 \%$ of the budget of an approved film project. The managing authority is the executive agency of the "National Film Center", which has no financial autonomy, but is an administrative and corporate body under the governance of the Ministry of Culture.

Today, the Bulgarian film industry achieved manifold higher economic contributions through added value as compared with public subsidies received. Feature films supported by Bulgarian National Film Center completed in 2015 were 25. The aim of the present study is not only to assess the economic contribution of the film industry, but also the characteristics of cinema in Bulgaria as a market sector by analyzing economic growth, employment, and investment.

\section{The Literature Review}

Over the years of transition (the last twenty-five years), the research and academic interest in the Bulgarian film industry has been limited, which led to scarcity of data.

While there is a shortage of focused research on the topic, there are many studies and publications on individual aspects about the nature of the film product. Findings of Debande and Chetrit (2001) have indicated that specificities of the audiovisual sector are reason of state regulation.

According to Ognyanova (2005) and Andreeva (2009), the sustainable development of audiovisual industry met serious obstacles including scarce financing mainly from the budget and lack of alternative financial instruments.

Tomova and Andreeva (2016) conducted series of empirical researches and according to their findings film industries have a significant economic effect on development cultural market in Bulgaria.

\section{Method}

The subject of the present article is the Bulgarian film industry and an analysis of its economic contribution assessed through the mapping toolkit, and the objective is to make recommendations for a sustainable development of the sector. 
The analysis for this article is based on data on the project "Economic contribution of the arts, cultural, creative industries, and cultural tourism in Sofia" and for whose purposes, a scientific national survey "Mapping the cultural and creative industries in Sofia" was applied; data from the National Statistical Institute; and analysis of the legislation in the sector, management decisions of the National Film Center, the Ministry of Culture, and the Commission for the Protection of Competition.

The purpose of the analysis is to cover the Bulgarian film industry in economic terms by measuring and positioning it through the classic economic indicators revealed by the mapping study approach.

When looking for a new model for coverage and evaluation of cultural activities in the late 90s of the last century, the mapping study toolkit appeared and was developed - a method of measuring quantitative assessment of the creative sector through indicators typical of the classical economy. The beginning was put forward by the UK's Department of Culture, Media and Sport through their first research on the creative sector by means of the mapping approach. Mapping has enabled emancipation of the arts, cultural, and creative industries in the world of economy. They were given the opportunity to become independent in their own theoretical definition, which finds statistical coverage where this aspect made them measurable and comparable.

Mapping is a systematic approach to identifying and classifying the cultural resources of a city, region, or a country. The steps in the process are to collect, analyze, and synthesize cultural resources in the overall system of creative industries. The methodology in practice in Bulgaria is based on the mapping study of the arts, cultural, creative industries, and cultural tourism that reflects the established European practices of the national specificity of the cultural sector. The methodology is based on the EUROSTAT approach, i.e. the data are comparable. The approach to shaping the scope of the arts, the cultural and creative industries, and in particular the film industry follows the recommendations of the Leadership Group on Cultural Statistics reflected in the European Statistical System Network on Culture (Bina et al., 2012).

The algorithm of the methodology goes through three stages:

1. The subject of statistical observation is theoretically determined, for example, by the "film industry", by defining what this term implies;

2. Based on the existing statistical classifiers such as "Classificatory ot the economic activities", this first and broadest definition is limited to real-sector statistics activities in this sector (Bachvarov, Balkanjieva, \& Angelova, 2008). This is so-called "Statistical definition", i.e. the general definition is limited to specific activities in this case monitored by Structural Business Statistics;

3. The last narrowing of the subject is to "operational statistical definition", where activities with obvious cultural content continue to exist, excluding activities in this sector that are monitored by statistics, but have no cultural nor a partial content. Thus, Table 1 shows the final range of the film industry. 
Table 1

Range of the Film Industry according to the Economic Activity Classifier

\begin{tabular}{ll}
\hline Code & Activity \\
\hline 59.11 & Motion Picture and Television Broadcasting Services \\
59.12 & Technical Activities Relating to the Production of Films and Television Programmes (Post-Production) \\
59.13 & Distribution of Films and Television Broadcasts \\
59.14 & Film Screening \\
77.22 & Renting of Video Cassettes and Discs \\
\hline
\end{tabular}

When benefit is measured, value added is used at factor cost, which is an indicator imposed by EUROSTAT (rather than gross added value). It is accepted that this indicator can be obtained on accurate measurements in the field of cultural and creative industres, going down to the level of enterprise; turnover data and value added at factor costs relate only to non-financial enterprises; the time frame of the survey 2008-2015 allows for tracking the dynamics of observed indicators and outlining trends; and observed metrics involve number of enterprises, turnover, number of employees, value added at factor costs, direct foreign investment, and others.

\section{Results}

The film industry is a unity of four stages and multiple supplementary participants, including production, distribution, promotion, and film exhibition. This unity predetermines the division and participation of multiple sub markets in the entire cycle of a film. The film industry is a chain of segmented and related markets, namely investors, procedures, service providers available during production and post-production, distributors, and exhibitors or those involved in the presentation to the audience.

\section{Investors}

The state is a major investor through the National Film Center. According to National Film Center the public funding for the Bulgarian film industry in 2015 was around EUR 6,750,000 (BGN 13,200,000) (Tomova et al., 2016). Other investors with a total sum of less than one million Euro were the Bulgarian National Television, the National Culture Fund (supports only film débuts) and the Municipality Cultural Programme of Sofia. Market funds in the budget of film projects in Bulgaria come from the prior sale of the distribution rights of a film.

\section{Producers}

The producers' market consists mainly of micro-companies. More than 700 independent producers are registered, but less than $10 \%$ of them have managed permanent employment through winning a project.

\section{Service Providers available during Production and Post-Production}

In the European Union where cinema has historically not developed on a studio basis, the system of film support has imposed a division between producers and film service providers. In this market, companies specialize in specific types of services, such as rental of shooting equipment, lighting equipment, and casting. Here, again, micro-companies dominate. 


\section{Distributors}

According to the national register there are 180 distributors. Only ten of them are visible in the market, where two companies dominate and have created an oligopolistic market.

\section{Exhibitors or those involved in the Presentation to the Audience}

The two dominating distributors, Alexandra Film and Forum, also own almost all newly built cinema halls for the past twenty years. They receive $83 \%$ of ticket revenue according to the Film Center's data. This merger between the distribution market and the screening market is a vertical integration prohibited by law.

Because of the leading role of state financial support, the film industry in Bulgaria has features of a quasi-market. This is the case at the production phase, but not at the distribution and film screening stages. In the context of this competitive environment and despite the numerous flaws in the market, the Bulgarian film industry shows a positive dynamic tendency of its main economic indicators for the period 2008-2015. This eight-year observation period by mapping the sector has produced indicators that may be considered as trends.

The Bulgarian film industry had positive eight-year dynamics for the period 2008-2015, under the observed economic indicators:

Added value - $138.1 \%$;

Organizations - $94.45 \%$;

Increase of employed and hired personnel $-71.8 \%$ and $71.4 \%$;

Direct foreign investments $-81.5 \%$;

The incredible results also contrasted with the trends in the Bulgarian economy during part of this period and the results include recession, decline in employment and increase in unemployment, negative economic growth at the beginning of the period 2009-2010, and an economic growth under 1\% for the period 2011-2012.

The added value at factor costs or the economic contribution of film industry was about 23,6 million euro (BGN 46 million) in 2008, rising to nearly 56 million euro (BGN 109.2 million) in 2015 - or well above twice the value.

In 2015 , the greatest contribution to the added value in the sector was that of film production and technical services. In contrast to the situation of the sub-market of the rental of video cassettes and discs, the indicators show a vanishing market. The dynamics of economic growth for the period 2008-2015 is impressive in terms of technical services (post-production) with a growth of $277 \%$. This increment reflects the expansion of film production and the incoming of new technologies. A large increase of $253 \%$ over the period also occurs in the distribution market. In this respect, the growth factors include an increase in the number of distribution companies, the number of films, an increase in the number of screens in major cities, and a higher ticket price.

It is no wonder that these two sub-markets were the recipients of mainly foreign direct investment. Distribution is an activity that is not as risky as production, and this fact had aroused the interest of the major television channels who became part of this market. They also attracted new investments in technical services. 
The film industry realized many times higher economic contribution through added value compared to public subsidies received through the Bulgarian National Film Center, the Bulgarian National Television, the European Media Program, the National Culture Fund, and Sofia Municipality. For example, for the year 2015, the added value was 56 million euro, and the public subsidy from all sources was about 7,9 million euro.

Over the eight-year period, the number of companies in the film industry has steadily grown, and today there are almost 900 organizations. Most companies are at the stage of production. These represent over 55\% of all companies in the film industry. However, companies providing technical services (post-production) showed a peak growth of $184 \%$ during the period in question. Enhanced specialization is one of the reasons for this growth.

The Bulgarian film industry is dominated by micro-companies that have at most two employees. These firms account for $80 \%$ of all organizations in the sector and can be called "nano companies" because of their small size. Companies with up to 10 employees represent $15 \%$ of the film market.

There is a tendency of many new micro-companies emerging, but these have increasingly difficult access to state funding. This trend creates a market failure and forces them to search for new projects in all possible audiovisual markets, or to drop out of the race. Limited public subsidies create strong competition for winning a share of the cake, but they fall short of stimulating the pursuit of a high real income from the final product itself (Tomova, 2014).

The number of employed persons increased by $71,8 \%$ over the eight-year period. In the film industry 3,117 people were employed in 2015 , with $88 \%$ of them in production and postproduction. An important feature of this sector is the very high number of persons hired by temporary contracts $-2,559$ people (2015). This means that during a project, i.e. the making of a movie, workers in the sector grew by $82 \%$.

\section{Discussion and Conclusion}

The film industry has a complex production process. In this business, we often observe information asymmetry between unfocused demand and oversupply. Unreliable return coupled with high capital demand defines the product as risky and with high running costs.

This conclusion is also a rational argument for state support, which predetermines the leading role of public funding of the film industry not only in Europe or Bulgaria, but also in other parts of the world. The multiplied effect of public investment in Bulgarian cinema proves that the role of the state as an investor is decisive at the macro level. In Bulgaria, public investment has awakened production demand and managed to convert this market from a crisis state into a successful one. For sustainability, this trend requires further actions as follows:

Stabilization of micro-production companies through greater access to alternative capital resources. This opportunity will give the establishment of a fund "Bulgarian cinema". It is expected that the funds will be collected on a market principle.

The current competitive environment has market failures that need to be eliminated, namely the distribution oligopoly and the vertical integration between distribution and screening. 
Increasing the funds ear-marked for the promotion of Bulgarian films. Promotion and advertising are factors to overcome information asymmetry, a disadvantage for all film markets around the world.

A compulsory TV show for promoting the production of documentaries and cartoons by amending the Radio and Television Act.

Extending the access of the audience to Bulgarian films by using the network of "chitalista" (specific local cultural centers) to screen films. In this way, the oligopoly in distribution where Hollywood production excels can also be overcome.

The mapping survey provides an opportunity for better management of the sector and informed decisions based on detailed knowledge of the economic characteristics of the industry. A more effective institutional management of the Bulgarian film industry can be achieved by turning the National Film Center into a separate agency independent of the Ministry of Culture. This legal and managerial independence will also give financial freedom and the opportunity to implement the reforms mentioned above.

Research on which this article is based was supported by Sofia Municipality, administered by the Observatory of Culture Economics in Sofia, in partnership with the National Statistical Institute, which provided the data on a methodology constructed by the Observatory team.

\section{References}

Andreeva, D. (2009). Opportunities of the investment instruments for financing the cultural sector in Bulgaria. Annals of Doctoral Studies, 1(1), 117-145.

Bachvarov, R., Balkanjieva, V., \& Angelova, M. (2008). Classificatory of the economic activities. Sofia: NSI.

Bina, V. at al. (2012). European statistical system network on culture final report. Luxembourge: ESTAT

Debande, O., \& Chetrit, G. (2001). The European audiovisual industry: An overview. Luxembourge: EIB.

Ognyanova, N. (2005). EU audiovisual policy and legislation. Sofia: Sofia University: Sv. K1. Ohridski.

Tomova, B. (2014). The Bulgarian film industry: The sun and the shadow of the transition. Markets. Policies. Deficits. Scientific Papers of UNWE, 3(5), 197-231.

Tomova, B., \& Andreeva, D. (2016). Bulgarian media: economic contribution in a transforming environment. In S. Tcankova, B. Tomova, \& S. Konstantinova (Eds.), Economic and professional transformations in the convergence media environment (pp. 11-43). Sofia: UNWE Stopanstvo. 